\title{
Peertechz
}

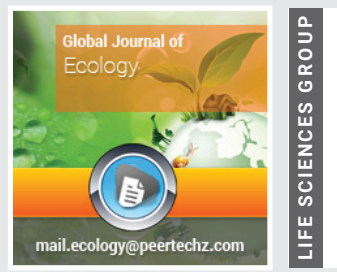

\section{The Role of Climate Change}

in the Dynamics of the

\section{Kazakhstan Population of Saiga (Saiga Tatarica L.)}

Received: 19 July, 2017

Accepted: 05 December, 2020

Published: 09 December, 2020

*Corresponding author: Murat Nurushev, Faculty of Natural History, L.N. Gumilyov Eurasian National University, $5 \mathrm{~K}$. Munaitpassov Street, Almaty Raion, Astana 010000, Kazakhstan, Tel: + 77072407458 .

E-mail:nuryshev@mail.ru

Keywords: Climate change; Warming; Biometeorology; Saiga; Epizooty

https://www.peertechz.com

Check for updates

\section{Murat Nurushev ${ }^{1 *}$, Assel Nurusheva ${ }^{1}$ and Azim Baibagyssov $^{2}$}

${ }^{1}$ Faculty of Natural History, L.N. Gumilyov Eurasian National University, 5 K. Munaitpassov Street, Almaty Raion, Astana 010000, Kazakhstan

${ }^{2}$ Scientific-Research Institute of Ecology, Al Farabi Kazakh National University, Almaty, Kazakhstan

\section{Abstract}

This article submits the analysis of the study of the climate change and its influence on dynamics of the number of saigas in Kazakhstan, which appeared 20 thousand years ago as a mammoth and a rhinoceros. The analysis concentrates on the study of the climate change influencing the mass murrain of antelopes (saigas) from the beginning of a new century.

Since the beginning of a new century their quantity has decreased by 3-10 times owing to two factors: epizooty pasteurellosis caused by the climate change and sharp reduction of a genetic variety. The environmental disaster connected with the mass murrain of saigas is caused by full insufficiency of information about the field of the wind (shifts) in the lower layers of the atmosphere.

It is necessary to bring the Doppler-radar installation in the obligatory list of meteorological devices by the expeditious definition of distribution of the field of the wind (wind shears) in the lower layers of the atmosphere. Especially it concerns the regions of the way of migration of the population of saigas. Otherwise, environmental disasters due to the dangerous external influence of the environment - fields of the wind (shifts) will continue.

In epizooty, the zone during one week had 3-4 norms of a monthly deposit, caused by the change of the western cyclone into the northern one.

High humidity, the main factor of the murrain of saigas, causes anaerobic enterotoxemia and pasteurellosis.

\section{Introduction}

Climate change of Anthropogenous and its influence on the environment (plant and animal life) - are an integral part of a bio-meteorological problem [1]. The climate change is connected with frequent transfer of heat and humidity in the atmosphere of the Asian continent which leads to the increase of the weather cataclysms - drought, hot dry winds, tornado, floods and hail [2].

The analysis of the data, including rings of trees, corals, ice cores, etc., gives the opportunity to the authors $[3,4]$ to claim that the rise of temperature of the surface of the sea happened twice more slowly than the air temperature did over the land.

The registered data of observations indicate the existence of considerable variability of temperature. So, in the 2othcentury the rise of temperature within two periods took place: from 1910 to 1945 and from 1976 to 2000. It is very probable that a decade from 1990 to 2000 had been the warmest for the entire period of observations since 1861, and 1998 was the warmest in all history of instrument observations [5].

The climate change in the territory of Eurasia within the 2oth century is confirmed by the researches [6]. It is 
confirmed by the long-term researches $[7,8]$ devoted to the bio-meteorological researches published in the International Journal of Biometeorology.

According to our data, in comparison with the prior period within the last 40 years the annual average of air temperature had increased by $1.1{ }^{\circ} \mathrm{C}$ and the rain had increased by $63.1 \mathrm{~mm}$.

The studies of the air temperature during the 80-year period show a steady tendency of increase with the considerable vibration amplitude from $1.4{ }^{\circ} \mathrm{C}(1942)$ till $11.1^{\circ} \mathrm{C}$ (1995) (Figure 1).

Dynamics rainfall during the 80-year period of observations showed that in the average amount in a year $303.8 \mathrm{~mm}$ of their amplitude of oscillations ranging from $121.6 \mathrm{~mm} \mathrm{(1936)} \mathrm{to}$ $522.3 \mathrm{~mm}(1946)$ of the precipitation fall out and in general had a steady tendency of increase (Figure 2).

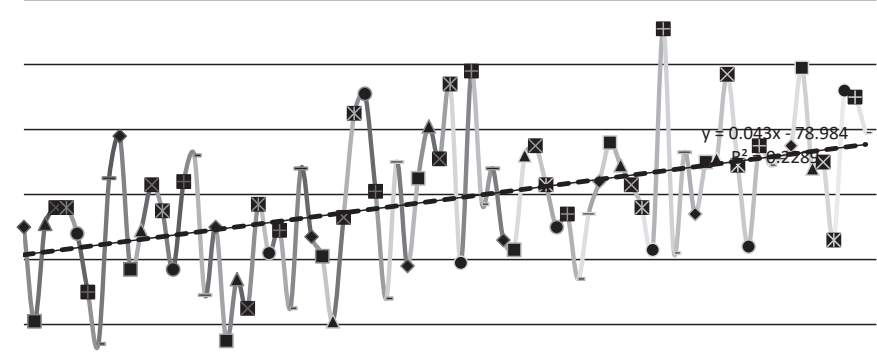

$\rightarrow$ Atmospherical temperature

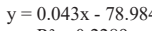

Figure 1: Dynamics of air temperature for the period (March-May) from 1935 to 2014

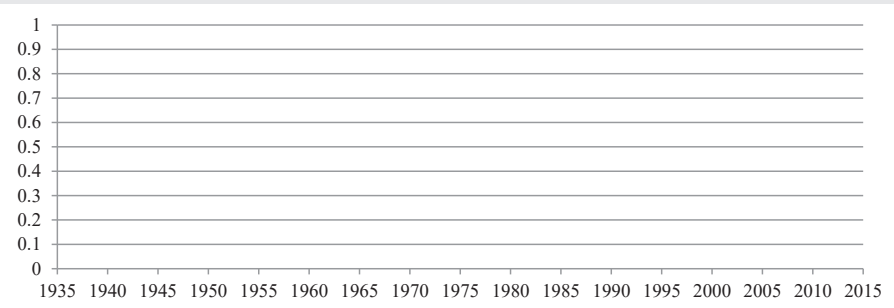

Figure 2: Evolution of average annual heavy rain within a year since 1935 for 2014.

From 1975 to 2014 the average annual sum of rainfall precipitation had increased by $63.1 \mathrm{~mm}$ and had reached $335.3 \mathrm{~mm}$. It should be noted that within the 20th century in Kazakhstan since 1970 the air temperature had increased and from this point the thirty-year tendency of temperature raised and a weak tendency to its stabilization in the last fifteen years takes place.

Steady preservation and biological diversity in the global and in the regional aspect are the universal guarantors of the existence of the organic life on Earth [9]. Saigas are the most ancient, hoofed animals of Eurasia. Like a mammoth and wooly rhinoceros they endured a glacial era 20 thousand years ago. In Kazakhstan the most numerous animal among wild hoofed animals is the saiga - Saiga tatarica L. In the recent past it was a background species of hoofed animals, which exceeded 1.0 million heads in the number.

Nowadays three populations of saigas live in the Republic of Kazakhstan; they are almost completely isolated from each other - betpak-dalinsky, Ustyurt and Ural [10]. Until the end of the last century, saigas were widely used as a trade species. The meat was in great demand with the population and the skin was used for the production of high-quality suede. For five years (1981-1985) in Kazakhstan 900 thousand saigas were shot. About 14 thousand tons of meats were produced. The production cost (including export of meat and horns) from this animal made about 19 million rubles, and the net profit cost 10 million rubles [10].

\section{Materials and methods}

Studying a bioclimatology the method of "interactions between live organisms and factors of the atmosphere of the environment" was applied [11]. In the analysis of the climate change there were used Reports on the results of the assessment of the Intergovernmental Panel on Climate Change [5].

In the research there were used such main methods as: a descriptive method at a laying of the trial areas for collecting field material (biological objects), the description of habitats of saigas and other animal species; a comparative method - by comparison ecological and the epizootic processes and also the materials of the author's own researches, the published works, including electronic resources [12-22].

In the research there were used the weather service indicators located on the route of migration of saigas (Arshalinsk, Dokuchayevka, Esenkul, Zheleznodorozhnyi, Zhitigara, Kamysty, Karabalyk) in the period of their mass murrain.

In order to investigate the plant community structure, a quadrat-based study was undertaken which enables fine scale information about the plant community to be collected whilst also, with a sufficient number of quadrats, providing information about the larger area. A number of considerations must be taken into account when conducting a study which uses quadrats, including the size and shape of the quadrat. Choices for both may be informed by the literature [23,24] - squareshaped quadrats, for example, are most commonly used. The extent to which the pasture analysis data can be interpreted is severely limited due to the small quantity of data collected.

\section{Results}

\section{Features of biology and the future prospect of the saigas ecotype in Kazakhstan}

Field researchers specify [25] the saiga diet which includes plants such as: anabasis (Anabasis aphylla L.), bug-infested (Lepidium), Kermek (Limonium Vulgare), ephedra (Ephedra distachya) and others which differ in nutritious and medicinal properties, but aren't eaten by farm animals. Saigas are constantly wandering animals.Within a year, they cover 3-4 thousand kilometers (Figure 3). 


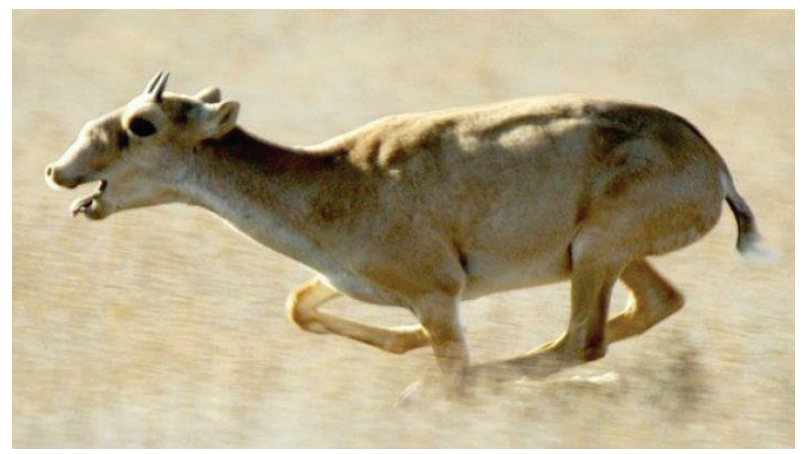

Figure 3: Saiga - a unique type of hoofed animals, the age-mate of a mammoth and rhinoceros.

Saigas often change pastures and, as a rule, only partially pit vegetation. Their diet consists of different plants, which are reluctantly or completely not eaten by the livestock (anabasis, bug-infested, Kermek, ephedra, etc.).

The most selective animal among pets is the horse. So, according to our researches on Ustyurt from 616 species of plants, the adayevsky horse ate only 77 , i.e. only every eighth of all herbs a day [26]. In view of that a saiga among the big range of vegetation consumes only 20 kinds of herbs, i.e. selectivity of saigas in the choice of vegetable food is very high (1:50). Saigas eat only every fiftieth of a set of kinds of vegetation. Generally it is juicy grass: Sálsola, Ephedra distachya, various species of worm wood (Artemísia), wheat grass comb (Agropyron pectinatum), Mortuk (Eremopyrum triticeum), Kentucky bluegrass (Poa praténsis), fescue (Festúca valesiáca), Kermek (Limonium vulgar), boy Aly ch (Salsola arbuscula), Kokpek (Atriplex cana), Anabasis salsa (Anabasis salsa), kochia (Kochia scoparia), sorrel (Rúmex), which accounted for $98 \%$ of the stomach contents. Careful analysis showed that most of them are not only nutritious but contain medicinal properties [25].

On our hypothesis, in those herbs which are eaten by saigas there is a mystery of anti-neoplastic drugs (treatment of cancer tumors). First, they are the most ancient hoofed animals which since the Ice Age have lived up to now. Secondly, they have no cancer and other diseases of people.

The natural congenital instinct of saigas on the selectivity of officinal herbs can prompt us many secrets of treatment of oncological diseases. We have to study the elementary behavior of a saiga more deeply and reveal secrets of health and longevity.

Thus, on the basis of the association - Artemisia pauciflora which are eaten by a Kazakh horse, the Kazakhstani academician Sergazy Adekenov developed the effective anti-neoplastic medicine "Arglabin" (Patent USA №6,242,617, B1, Jun.5.2001; Europian Patent № 0946 565, 15.10.2003; Deutschen Patent № 697 2504.9-08, 23.10.03; Swiss Patent 97947981.3 (CH) EP 0946565; Patent of China ZL 20068 0055852.4, 26.12.2012) [26]. On our hypothesis, we assume that on the basis of herbs what saigas eat, perhaps, we can create even more effective medicine. These and other factors confirm the need to keep a biodiversity of a saiga on our planet.
If the most selective animal among pets on vegetation is the horse that eats every eighth of all the grass, the saiga consumes only 20 of the thousands of species of steppe plants, i.e. every fiftieth. We found it out studying the food behavior of betpak-dalinsk population in lower reaches of the Sarytorgay River. Generally, these are juicy herbs: glassworts, an ephedra, different types of ice-holes, a wheat grass pectineal, Kentucky bluegrass, fescue, Kermek boyalych, Kokpek, Anabasis salsa, kohii, sorrel that made $98 \%$ of the volume of contents of stomachs. Thus, only $12-23 \mathrm{Kg} /$ hectare of vegetation a year (about 1.5-2\% of a crop) are used for food while pets use 100 and more $\mathrm{Kg} /$ hectare $(12-18 \%)$, that shows a weak load of pastures.

The feeding capacity of pastures of the Republic in full prosperity can provide an annual ration from 2 to 3 million saigas, without damaging the environment. All this testifies to possible enormous prospects of cultivation of steppe antelopes in the territory of Kazakhstan not only as the specific variety but also in the long term as a trade type of hoofed animals $[9,25]$.

The current most plausible hypothesis for the die off of saigas in West Kazakhstan in 2010 and 2011 is that, after calving, adult saigas entered an area of relatively rich pastures. This was a time of rapid growth of vegetation. After eating the vegetation, saigas developed problems with their ruminal function. This led to bloating, mild diarrhea and a respiratory based sudden death syndrome, similar to "Fog Fever" [27].

Despite the general trend of increase through the second half of the 2oth Century due to Soviet regulation on hunting and trade [28], censuses from 1998 onwards show drastic declines in population numbers throughout the species' range. This is most likely due to increased poaching pressures for meat as a result of economic collapse in rural areas in the antelope's range [29] and, as the horn of the male is prized highly for use in traditional Chinese medicine, they are selectively hunted, resulting in a much skewed sex ratio and the recently observed reproductive collapse of the species [30].

In May 2010 and 2011 the post-calving Ural population of saiga suffered mass mortalities. These mortalities comprised $>12,000$ and 400 individuals respectively [31] and the cause was officially reported to be pasteurellosis. In both years, after calving in mid-May, the population moved on to new pasture and suffered a severe die-off event over a period of only a few days. In 2010 the core period of die-off occurred from the 18th to 24 th May and the 2011 event occurred between the 26th and the 27th of May. The observed syndrome in adults was bloat, signs of asphyxia, and pink frothy nasal exudates pre- and post- mortem during both years [32]. The cause of the dieoffs was officially reported as pasteurellosis; however recent re-examination of the evidence [32] suggests alternative hypotheses due to a number of characteristics of the events.

Atypical Interstitial Pneumonia (AIP), also known as "fog fever" or Acute Bovine Pulmonary Emphysema and edema (ABPE) (Kerr and Linnabary, 1989), is a potential cause which is consistent with the rapid pathogenesis reported and 
observed in grazing adults, signs of asphyxia and pink frothy nasal exudates pre- and post- mortem during both years [32]. AIP occurs as a result of rapid pasture change; sudden exposure to lush quality pasture post-calving when animals are in peak lactation and hungry leads to rumen dysfunction due to the limited ability of the rumen to adapt to a sudden increase in the nutrient quality of forage [33]. High protein content, specifically of the amino acid L-tryptophan, leads to the production of 3-methylindole during ruminal fermentation and results in edema and emphysema, a potential cause of the observed symptoms.

Thanks to their hoofs there is a pollination of many rare plants, steppe endemic. These materials testify to possible enormous prospects of the dwelling of steppe antelopes in the territory of Kazakhstan, not only as a specific variety but also as a trade type of hoofed animals.

In Kazakhstan 1.7 million sq.m of valuable skin were made from saigas and 90 thousand tons of meat, 250 tons of horns were exported, the gained income from trade averaged about 3.0 million US dollars on average [34].

Saiga, as well as horse, the sign animal in Central Asia personifies development of a steppe civilization. In Kazakhstan the most numerous animals among wild hoofed animals are the saigas - as ancient as a mammoth and rhinoceros which endured a glacial era 20 thousand years ago. In the recent past it was a background type of hoofed animals the number of which exceeded 1 million heads. Nowadays three populations of saigas which are almost completely isolated from each other - betpak-dalinsko-arysskaya, Ustyurt and Ural live in the Republic.

Now on the border of four areas - Karaganda, Kzyl-Orda, Aktyubinsk and Kostanay the state fund for the rescue of saigas (on the initiative of Margulan Seysembayev and Murat Nurushev) defines borders of a public reserve of "Akshala". As a symbol of the revival of saigas, the ecological society intends to approve a public reserve of "Akshala". The territory of the future reserve will make more than 1 million hectares or more than 10 thousand sq. kilometers.

The last epizooty, large on the scales, is noted in May 2015 in the territory of three areas (The Kostanay, Aktyubinsk, and Akmola region). In total as of June 22, 2015 148, 800 carcasses of saigas were utilized.

So far the experts had two key versions of the causes of a mass murrain. The first, the main one, was based on the climate change reason when in this zone in one week 3-4 rainfalls dropped out that was caused by the change of the western cyclone to the northern one. Kazgidromet's data demonstrated much rainfall exceeding the norm on the place of the mass case of saigas' murrain which was followed by a sharp fall of temperature and intensity of the wind. So, according to the data of meteorological stations, during the first ten days of May there was heavy rain precipitation approximately to 75 $\mathrm{mm}$ having the norm of 8-10 $\mathrm{mm}$ a month.
Certainly, it is the major factor which caused an acute tympanites of the cicatrix of a stomach of a saiga with the transition to an anaerobic enterotoxemia and pasteurellosis. Eating the juicy green grass moistened with a plentiful atmospheric precipitation causes illness of animals. Fermentation of a forage in the alimentary system of saigas provokes rough reproduction of the corresponding bacteria (inflation) emitting the toxins getting through blood vessels and internals, striking a nervous system.

Appreciable weakening of a maternal organism was promoted also by age biology of a fetus. In the last month pregnancies, the mass of a fetus is enlarged twice. Considering that saigas can delay terms of childbirth in adverse days (in search of the dry place), the provision of maternal individuals becomes complicated even more. In the bulk, the maternal livestock fell, and their significant amount fell at a stage of labors.

\section{Features population dynamics}

In the territory of Kazakhstan, the main part (80-85\%) of a modern area of this species is concentrated. Insignificant fragments of the area of distribution are available in the Russian Federation, Uzbekistan, Turkmenistan and Mongolia. Three geographical populations of saigas live in our Republic: betpak-dalinsk (between Balkhash and the Aral Sea), ustyurtsk (between the Aral and the Caspian Sea) and Ural (in the interfluence of the Ural and Volga rivers). Some part of the ustyurtsk population for the winter migrates to the South of the neighboring Uzbekistan and a lesser extent to Turkmenistan. A certain part of the Ural population reaches the border regions of Russia. The approach of spring migration of animals is observed in the opposite direction of the territory of Kazakhstan.

The number of saigas is subject to sharp fluctuations. If in 1991-1993 in Kazakhstan there were 800-900 thousand saigas, but in the next six years they decreased in their livestock proceeded (Table 1 ).

During the period from 2005 to 2009 , in comparison with 2003, the number of these hoofed animals increased slightly and that is a consequence of strengthening the security actions, and also, rather favorable weather and a climatic factor at this interval of time. For example, the livestock of betpakdalinsk population increased from 32.3 thousand heads in 2008 to 45.2 thousand in 2009 , i.e. by $39.9 \%$. The number of ustyurtsk population of saigas for this period decreased by 1.2 thousand individuals and continues to decrease gradually. The main reason is inefficient protection and a considerable press of poaching in the territory of Uzbekistan where the saiga migrates on wintering during the winter period. On the contrary, the number of the Ural population increased from 18.3 thousand in 2008 to 26.6 thousand heads in 2009 , i.e. by $45.3 \%$. This tendency is observed in recent years. For example, in 2015 their livestock already almost doubled.

Since 2010 the absolute number of saigas has begun to increase considerably. In a section of the population, there should be noted the steady growth of the Ural population of 
Table 1: Dynamics of number of saigas in Kazakhstan for 17 summer period (19992015)

\begin{tabular}{|c|c|c|c|c|}
\hline \multirow{2}{*}{ Years } & \multicolumn{2}{|c|}{ Name of population, considered, thous.heads } & \multirow{2}{*}{ Total } \\
\cline { 2 - 4 } & Ural & Ustyrt & Betpakdalinsk & \multirow{2}{*}{348,0} \\
\hline 1999 & 84,0 & 200,0 & 64,0 & 148,0 \\
\hline 2000 & 17,5 & 116,0 & 150 & 79,3 \\
\hline 2001 & 9,3 & 58,0 & 12,0 & 30,0 \\
\hline 2002 & 6,9 & 19,1 & 4,0 & 21,2 \\
\hline 2003 & 6,5 & 12,9 & 1,8 & 30,7 \\
\hline 2004 & 8,8 & 15,0 & 6,9 & 39,6 \\
\hline 2005 & 10,0 & 19,6 & 9,9 & 47,4 \\
\hline 2006 & 12,8 & 17,8 & 16,8 & 54,8 \\
\hline 2007 & 15,6 & 16,4 & 22,8 & 61,0 \\
\hline 2008 & 18,3 & 10,4 & 32,3 & 81,0 \\
\hline 2009 & 26,6 & 9,2 & 45,2 & 97,4 \\
\hline 2010 & 39,1 & 4,9 & 53,4 & 102,0 \\
\hline 2011 & 17,9 & 6,1 & 78,0 & 137,5 \\
\hline 2012 & 20,9 & 6,5 & 110,1 & 187,0 \\
\hline 2013 & 26,4 & 5,4 & 155,2 & 256,7 \\
\hline 2014 & 39,0 & 1,7 & 216,0 & 295,5 \\
\hline 2015 & 51,7 & 1,3 & 242,5 & \\
\hline
\end{tabular}

hoofed animals and gradual decrease in the Ustyurtsk. The major limiting factor of a number of saigas on Ustyurt is anthropogenous, their considerable shooting in wintering places, either from the Kazakhstani or Uzbek part of this plateau.

\section{Mass cases of murrain of Saigas}

Population of the saigas is constantly exposed to the influence of the limiting factors which are traditionally subdivided into atmospheric (weather and climate), biotic (predators, parasites, diseases) and anthropogenous (intervention, the economic activity of the person). In the last decades (60 years), essential causes of death have been caused by climatic factors: heavy winters (snow thickness), damp spring (frequent heavy rain), and also epizooty of a footand-mouth disease and pasteurellosis. In total, in Kazakhstan for 60 summer periods by our estimates about 700 thousand saigas were lost. Predation, mainly wolves has no so noticeable impact on the populations of saigas. This factor has constant character and generally eliminates a drop, old, sick, among them wounded, and also young individuals (only 1-2\%).

It is established by us that saigas are representatives of hoofed dry steppes and deserts. They feel badly in the rainy spring and in the winter with the large volume of snow. Global climate change in the territory of Kazakhstan is characterized by steady pouring rains and the change of one cyclone by another in separate years. It negatively influences dynamics of the population of saigas and it caused mass murrain during these periods.

The last large-scale epizooty is noted in May 2015 in the territory of three areas at once. The first case of mortality (117 individuals) of saigas was registered on May 11 in the natural boundary of the Zholaba Zhangeldinsk area of the Kostanay region (Figure 4).

At the same time, the mass case was noted in the Aktyubinsk and Akmolinsk areas. In total, for June 22, 2015 148,800 carcasses of saigas were utilized. From them in the Kostanay region -127,775, Aktyubinsk- 10,358 and Akmolinsk -10,667 heads.

Large-scale epizooty of pasteurellosis (May 2015) caused an ambiguous reaction and a rough public response. There were many hypotheses which interpret the version of the reasons for emergence of a mass case of saigas' murrain. The majority of the versions have the right for existence until the true reason of this catastrophic natural phenomenon is not established.

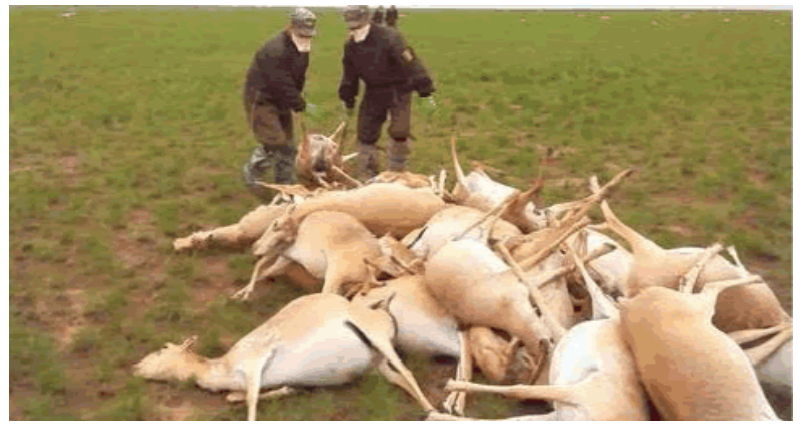

Figure 4: The mass death of saiga in the south Kostanay region.

1. The tympanites of a hem of a saiga's stomach occurs when there is swelling owing to fermentation in it when they eat green grass.

2. The anaerobic enterotoxemia is arising also while animals are eating the juicy green grass moistened with plentiful atmospheric precipitation. Fermentation of forage in a gastrointestinal tract of saigas provokes rough reproduction of the corresponding bacteria emitting the toxins getting through blood vessels into all internals, also striking a nervous system.

3. A group of versions try to explain the cases of saigas' infectious (bacteria and viruses) and parasitic diseases.

4. There is a hypothesis of being poisoned with fuel from the space rocket of Baikonur Cosmodrome containing poisonous components or pathogenic microorganisms from the Soviet biological weapon.

The majority of the given hypotheses are rejected by researchers as not confirmed. For example, the hypothesis according to which the murrain of saigas occurs because of being poisoned with the rocket fuel heptyl which contains poisonous components including the remnants of the Soviet biological weapons. The latest accident of the carrier rocket "Proton-M" took place on May 16th and the first death cases of saiga were noted earlier, on May 10-11, 2015, in a completely different area. Particularly, according to the Russian Agricultural Supervision in reference laboratory of especially dangerous diseases carried out on June 1-2, 2015, analyses of the pathological material of saigas from Akmolinsk, Aktyubinsk and Kostanay areas in all tests Pasteruellamultocida, type B, the activator of a hemorrhagic septicemia or pasteurellosis, is found. This illness also became the reason of a mass case of saigas in Kazakhstan [25]. 
The first and the main one was based on the climate change when in this zone during one week there dropped out 3-4 norms of precipitation, caused by the western cyclone change to the northern cyclone. Kazgidromet's data demonstrate the exceeding norm of precipitations on a place of the mass murrain of saigas in the Kostanay region that was followed by a sharp fall of temperature and strengthening of the wind. Therefore, according to an area of the meteorological station for the first decade of May there dropped out from 17 to 75 millimeters of rainfall precipitation at the norm of $8-10 \mathrm{~mm}$. (Ekiden - $17 \mathrm{~mm}$, Railway - $35 \mathrm{~mm}$, Zhitigara - $75 \mathrm{~mm}$ and Karabalyk $-53 \mathrm{~mm}$ ). These stations are located in the ways of migration of betpak-dalinsky population.

Certainly, it is the major factor, which caused a sharp tympanum of a hem of a stomach of a saiga with the transition to an anaerobic enterotoxemia and pasteurellosis. The illness is caused by eating the juicy green grass moistened with plentiful atmospheric precipitation by the animals. Fermentation of food in the digestive system stimulates rapid reproduction of the corresponding bacteria (swelling) emitting the toxins which get through the blood vessels and internals, striking the nervous system (Table 2).

A significant weakening of the maternal organism of saiga was promoted also by age biology of a fetus. In the last month of pregnancy, the mass of a fetus increases in weight twice. In the most part an adult uterus perished, their essential quantity has died at a stage of childbirth.

A sharp decrease in immunity of an animal brings to pasteurellosis (pasteurellosis; a synonym of a hemorrhagic septicemia) - the infectious disease relating to the group of zoonoses, proceeding as a septic disease. It is necessary to adjust a complex scientific support of cultivation of all three populations of Kazakhstan (Betpak-dalinsky, Ustyurt and Ural). The causative agent of pasteurellosis is Pasteurella bacteria of Brucellaceae families. They possess pathogenicity.

Table 2: The sums of an atmospheric precipitation (May, 2015) according to eteorological stations Kostanay region, $\mathrm{mm}$.

\begin{tabular}{|c|c|c|c|c|c|c|}
\hline \multirow{2}{*}{ Station } & \multirow{2}{*}{ Area } & \multirow{2}{*}{ Index } & \multirow{2}{*}{$\begin{array}{c}\text { Norm } \\
\text { Fact }\end{array}$} & \multicolumn{3}{|c|}{ May (decade) } \\
\hline & & & & I & II & III \\
\hline $\begin{array}{c}\text { Arshalinsk temporary storage } \\
\text { warehouses }\end{array}$ & Denisov & 28948 & Norm & 9 & 10 & 13 \\
\hline $\begin{array}{c}\text { Arshalinsk temporary storage } \\
\text { warehouses }\end{array}$ & Denisov & & Fact & 57 & 35 & 12 \\
\hline $\begin{array}{c}\text { Dokuchaevka atmospheric weather } \\
\text { service }\end{array}$ & Altynsarinsk & 63517 & Norm & 10 & 7 & 12 \\
\hline $\begin{array}{c}\text { Dokuchaevka atmospheric weather } \\
\text { service }\end{array}$ & Altynsarinsk & & Fact & 43 & 50 & 14 \\
\hline Esenkul & Karabalyk & 63506 & Norm & 9 & 10 & 13 \\
\hline Esenkul & Karabalyk & & Fact & 64 & 20 & 10 \\
\hline Railway (Zheleznodorozhnyi) & Karasu & 35064 & Norm & 9 & 8 & 14 \\
\hline Railway Zheleznodorozhnyi) & Karasu & & Fact & 35 & 17 & 8 \\
\hline Zhitigara & Zhetikary & 35042 & Norm & 8 & 11 & 14 \\
\hline Zhitigara & Zhetikary & & Fact & 75 & 19 & 13 \\
\hline Kamysty & Kamystinsk & 63509 & Norm & 9 & 10 & 13 \\
\hline Kamysty & Kamystinsk & & Fact & 64 & 20 & 13 \\
\hline Karabalyk & Karabalyk & 28843 & Norm & 9 & 10 & 11 \\
\hline Karabalyk & Kamystinsk & & Fact & 53 & 27 & 4 \\
\hline
\end{tabular}

The disease is followed by a septicemia, symptoms of damage to the top airways and enteritis. The carriage of bacilli is very widespread.

Thus, among all sets of the abiotic, biotic and anthropogenous factors making the limiting impact on the population of saigas, first of all, a pasteurellosis epizooty has an essential biotic value.

\section{Discussion}

If in May 2017 in places of a mass childbirth of saigas there was cold and rainy weather, then their death from pasteurellosis is inevitable. But how to avoid a new case of mass murrain of animals? On the basis of the conducted researches we consider it necessary to carry out a number of preventive measures till spring of the next year:

1. The environmental disaster connected with the mass murrain of saigas is caused by full insufficiency of detailed information about the field of the wind (shifts) in the lower layers of the atmosphere. The sharp and dangerous changes in the field of wind generating cyclones can take place on any site and are fraught with incidents, including large-scale accidents on the way of migration.

It is necessary to bring the Dopler-radar installation in the obligatory list of meteorological devices by the expeditious definition of distribution of the field of the wind (wind shears) in the lower layers of the atmosphere. Especially, it concerns regions of the way of migration of saigas' population. Otherwise, environmental disasters due to the dangerous external influence of the environment - fields of the wind (shifts), will continue.

2. Only on the basis of the forecast of cyclones (rain), winds (change) in lower layers of the atmosphere of a migratory route of saigas it is necessary to execute bacteria nation. To carry out spraying of water solution with a saiga serotype of the antipasteurellosis vaccine developed at the faculty of veterinary science of the Kazakh National Agricultural University from helicopters at the small height of grassy vegetation. The unprecedented via vaccination should be carried out in April in territories of mass lambing of saigas. After eating the grass, it will be processed by a vaccine in their organisms, develop resistant immunity against pasteurellosis within several months. It will give the saigas a chance to endure the adverse period of the year.

3. It is necessary to create comfortable conditions to a uterine livestock for childbirth in places of mass lambing, especially to strengthen the protection of "rest zones". In such zones any economic activity (a cattle pasture, movement of cars, etc.) for 10-15 days before lambing and for 15-20 days after that has to be forbidden. An urgent task is a fight against wolves and stray dogs.

4. Comprehensive scientific support of research institutions at the international level concerning the weather forecast and biology of the migrating animals, with the single coordination Center in the city of Astana, is necessary. The Higher 
educational institution where there are qualified personnel, space monitoring and direct proximity to a research object can perform this work. To all these criteria there corresponds the L.N. Gumilyov Eurasian National University the scientists of which could become coordinators of the program for the salvation of saigas. Also, the experiment of Australia on the recovery of a kangaroo will be useful to us. We are sure that the assistance will be given from the Governments of RK and the international organizations: World Meteorological Organization (WMO), MSOP, YUNEP, WWF, and PROON.

The protected natural territories united in one ecological network are necessary for Kazakhstan. Basic elements of the protected territories will be national parks and the reserved territories which have to be connected among themselves by the protected objects of regional and local value. Creation of a global eco platform will represent the network of a full form. Otherwise, the isolated elements of the natural protected fund will undergo to the ecological deterioration because of an anthropogenous factor [9].

\section{Effect of "a bottle neck"}

Pasteurellosis epizooty often arises in May when saigas' lambing comes to an end. Mothers, which already gave birth, and their newborn posterity are physically weak for some time. The exhausted gene pool of the population causes weakening of the general immunity of this species. Decrease in the resilience of an organism (immunity) to the banal microflora, passerelle (which are often present in the organisms of healthy animals), provokes the fast increase of virulence of these microbes and as a result a high lethality of saigas (mothers and descendants).

In our opinion, exhaustion of a gene pool of a saiga is caused by close inbreeding (closely related crossing) of individuals in a lineage for the last 60 years. Initial Kazakhstani population of saigas in the late forties of the XX-th century didn't exceed 2-3 thousand heads. This phenomenon in the population of animals in genetics is called the effect of "a bottle neck" $[25,35]$. The concept of the effect of "a bottle neck" reflects the sharp decrease in a genetic variety or a gene pool of the population that occurs between two next cycles of dynamics of the quantity (critical recession and rise). The curve of the presence of livestock in the narrowest part is similar to a bottle neck and got such figurative name. The effect of "a bottle neck" was affected by laws of genetics, mainly, viability of animals. Earlier it was proved on the example of cheetahs. The similar situation led them to sensitivity and diseases.

\section{Conclusion}

1. The environmental disaster, connected with the mass murrain of saigas, is caused by a lack of information support of the forecast of cyclones, winds (change) in lower layers of the atmosphere. The obligatory Dopler-radar installation in the list of meteorological devices of the meteorological station by the urgent definition of the area of the wind (wind shears) in lower layers of the atmosphere is necessary. Otherwise, environmental disasters, because of the dangerous external influence of the environment - areas of the wind (change), will proceed.
2. Only on the basis of the forecast of cyclones (rain), winds (change) in lower layers of the atmosphere of a migratory route of saigas it is necessary to execute bacterination. It will give saigas a chance to endure the adverse period of the year.

3. On our hypothesis, in those herbs which are eaten by saigas there is a mystery of anti-tumoral drugs (treatment of tumors of cancer). The natural instinct, congenital in saigas on the selectivity of officinal herbs, can induce us to believe in many mysteries of processing of oncological illnesses. We have to study the alimentary behavior of saigas in the opening of medical secrets. These factors enlarge the need of conservation of saigas for the region to restore a genetic variety of the Kazakhstani subspecies of saigas (S.t. tata Rica) by the method of intraspecific crossing with the Mongolian (S.t. Mongolia) subspecies.

4. We are sure that assistance will be from: World Meteorological Organization (WMO), MSOP, YUNEP and World Wide Fund for Nature and PROON. Only the common harmonious efforts of scientists and management of the international institutes will help to keep saigas in the fauna of mammals of Kazakhstan.

\section{References}

1. Paul JB (2014) Climate change and biometeorology, the International Society of Biometeorology and its journal: a perspective on the past and a framework for the future. Int J Biometeorol 58: 1-6. Link: https://bit.ly/330iGdT

2. Nurushev MZh, Baygenzhin AK, Nurusheva AM (2013) Low-carbon development - The Kyoto Protocol: Kazakhstan, Russia, EU and line item of the USA (1992-2013): The monograph - Astana: Zharkyn Co LLP: 104-122.

3. Gruza GV, Rankova EY (1980) Structure and variability of observed climate. Air temperature of the Northern hemisphere. L. Gidrometeoizdat 72.

4. Clivar (1995) Study of climate Variability and Predictability. Science pbn: WCRP - 89. TD - NO/ 690. - Jeneva. Suitrerland:149-157Deutshchen Patent № 697 2504.9-08, 23.10.03; Europian Patent № 0946 565, 15.10.2003

5. Climate Change (2001) The Scientific Basis. Contribution of working group to the reassessment report of the intergovernmental panel on Climate Change / Houton JÒ, Dizi Grigas DJ (eds.). Cambridge, Cambridge University Press 566-571.

6. Izrael YUA, Semenov SM, Anisimov OA, Anokhin YUA, Velichko AA, et al. (2007) Fourth Assessment Report of the Intergovernmental Panel on Climate 50 Change: contribution of the Working Group II. Meteorology and Hydrology $5-13$

7. Höppe $P$ (1997) Aspects of human biometeorology in past, present and future Int J Biometeorol 40: 19-23. Link: https://bit.ly/37FzTY6

8. Gosling SN, McGregor GR, Lowe JA (2009) Climate change and heat-related mortality in six cities Part 2: climate model evaluation and projected impacts from changes in the mean and variability of temperature with climate change. Int J Biometeorol 53: 31-51. Link: https://bit.ly/2ljU4IE

9. Nurushev MZh, Baitanaev OA (2016) To keep biological diversity. Kazakhstan truth (National newspaper). No. 232: 23-24.

10. Afanasyev AV, Bazhanov VS, Korelov MN (1953) Animals of Kazakhstan. AlmaAta 502-536.

11. Sheridan SC (2007) A survey of public perception and response to heat warnings across four North American cities: an evaluation of municipal effectiveness. Int J Biometeorol 52: 3-15. Link: https://bit.ly/2Ldw1pl 
12. Baytanayev OA, Abayeva KT, Kentbayev EZ (2014) Saiga in Kazakhstan: effect of "a bottle neck". The Steppe bulletin - Novosibirsk 48-49.

13. Li CC (1955) Population genetics. Chicago: University of Chicago Press 281.

14. Meka-Mechenko TV, Nekrasova LE, Lukhnova LY (2014) The biological properties of the strains of pasteurellosis allocated in 2010-2013 in Kzylorda and West Kazakhstan areas of Kazakhstan. Materials of international scientific pract Conf. Ural anti-plague station. Uralsk 169-171.

15. Meldebekov AM, Bekenov AB (2009) Dinamik of number and protection of a saiga in Kazakhstan//Theriofauna of Kazakhstan and adjacent territories. Almaty 175-180.

16. Meldebekov AM, Bekenov AB, Bekenova NA (2014) Problems of preservation and reproduction of populations of a saiga in Kazakhstan. Modern problems of hunting economy of Kazakhstan and the adjacent countries. Almaty 5-8.

17. Zietkievicz E, Rafalski A, Labuda D (1994) Genome finders-printing by simple sequence repeat (SSR) - anchored polymerase chain reaction amplification. Genomics 20: 176-183. Link: https://bit.ly/37।Q3zJ

18. Fadeyev VA, Andlvanov AA (1988) The number of saigas in Kazakhstan depending on fodder resources. Proceedings of the Institute of Zoology of ANKaz. Soviet Socialist Republic t. 44. Alma-Ata 37-47.

19. Grachev YuA (2009) Structure and reproduction of populations of a saiga in Kazakhstan. Theriofauna of Kazakhstan and adjacent territories. Almaty 181 186

20. Kock R, Grachev Y, Zhakypbayev A, Usenbayev A, Zuther S, et al. (2012) A retrospective assessment of saiga antelope Saiga tatarica die-off in Western Kazakhstan 2010-2011. Saiga News 14: 1-4. Link: https://bit.ly/3ITEhrs

21. Jenkins M (2001) 101 key idea: evolution. M: Fair-press 227.

22. Williams JG, Kubelik AR, Livak KJ, Rafalski JA, Tingey SV (1990) DNA polimorphisms amplified by arbitrary primers are useful as genetics markers. Nucl Acids Res 18: 6531-6535. Link: https://bit.ly/3oy20En

23. Goldsmith FB, Harrison CM, Morton AJ (1986) Description and analysis of vegetation $437-524$

24. Krebs CJ (1999) Ecological methodology. Addison-Wesley Educational Publishers, Inc., Menlo Park, CA 620. Link: https://bit.ly/39NY4Gk
25. Nurushev MZH, Baitanaev OA, Kerimbai BN (2016) How to save the saiga in Kazakhstan?Science and World International scientific Journal 2: 96-100.

26. Patent of China ZL 8 0055852.4, 26.12.2012 Adekenov SM (2006) Method and device for production of lyophilized hydrochloride-18, 10 ${ }^{\beta}$-epoxy-13dimethylamino-guaia-3(4)-en-6,12-olide. Patent USA №6, 242, 617, B1. Link: https://bit.ly/2ljJKdm

27. Grachev Y, Zhakypbayev A, Usenbayev A, Zuther S, Klimanova O, et al. (2012) A retrospective assessment of saiga antelope Saiga tatarica die-off in Western Kazakhstan 2010-2011. Saiga Mortality - ongoing studies in Kazakhstan and Mongolia. Link: https://bit.ly/3ITEhrs

28. Nurushev MZH (2005) Adayevsky horse: evolution, current state, and prospects of cultivation. Astana. Astana Polygraphy 353.

29. Robinson S, Milner-Gulland EJ (2003) Political change and factors limiting numbers of wild and domestic ungulates in Kazakhstan. Human Ecology 31: 87-110. Link: https://bit.ly/37Koje8

30. Milner-Gulland EJ, Kholodova MV, Bekenov A, Bukreeva OM, Grachev luA, et al. (2001) Dramatic declines in saiga antelope populations. Oryx 35: 340-345. Link: https://bit.ly/33ROqi6

31. Milner-Gulland EJ, Bukreeva OM, Coulson T, Lushchekina AA, Kholodova MV et al. (2003) Reproductive collapse in saiga antelope harems. Nature 422: 135. Link: https://go.nature.com/3gl4G0o

32. Kock R (2011) Rapid Response to the Saiga Antelope (Saiga tatarica tatarica) Emergency in Western Kazakhstan, Report for Morris Animal Foundation Grant.

33. Carlson JR, Breeze RG (1984) Ruminal Metabolism of Plant Toxins with Emphasis on Indolic Compounds. J Anim Sci 58: 1040-1049. Link: https://bit.ly/3oAsIY9

34. Bykov LT, Gordiyenko OYA, Kukin VM (1967) About a susceptibility and immunity of big sandwort to pasteurellosis in the experiment. Materials of the V-th scientific conf. anti-plague institutions of Central Asia and Kazakhstan. Alma-Ata 348-350.

35. Baytanayev OA, Serikbayeva AT (2014) Saygak in Kazakhstan: zoological species or breed. Climate, ecology and agriculture of Eurasia. Irkutsk 79-82.

Discover a bigger Impact and Visibility of your article publication with Peertechz Publications

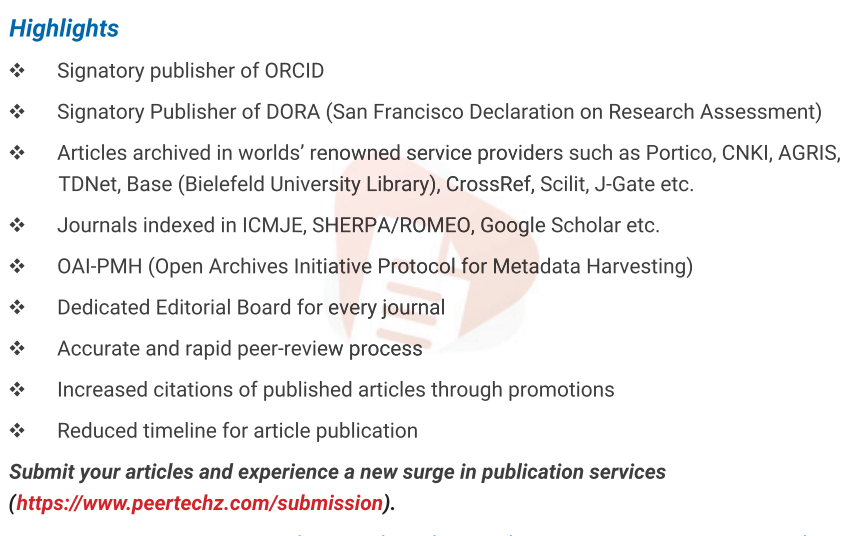

Peertechz journals wishes everlasting success in your every endeavours.

Copyright: ( 2020 Nurushev M, et al. This is an open-access article distributed under the terms of the Creative Commons Attribution License, which permits unrestricted use, distribution, and reproduction in any medium, provided the original author and source are credited. 